\title{
Of Unity and Disunity in-between: The post/colonial 'unhomely' in the works and lives of Jean Rhys and Hella S. Haasse
}

\author{
Stefanie van Gemert \\ University College London
}

\section{Abstract}

The Creole authors Jean Rhys - born on Dominica in the former British West Indies - and Hella S. Haase - from the former Dutch East Indies, now Indonesia - challenge the idea of temporally unified colonial pasts as neatly preceding the postcolonial present. They do so by blending past and present in works on decolonisation published in the UK and the Netherlands. The real-life events of the authors' colonial repatriation further stress that colonial unity is a construction. Within the colonial system, Rhys's and Haasse's biographical movements from the colonies to the European metropolises London and Amsterdam are considered re-turns to familiar motherlands (re-patriation). Yet Haasse and Rhys illustrate the complexities attached to these so-called 'returns' by staging and creatively appropriating them in their novels, showing a temporal and spatial disunity that proves to be inherent to both colonialism and post/colonialism.

Keywords: Post/colonial theory, Colonial heritage in literature, Nostalgia, Jean Rhys, Hella S. Haasse

Both the lives and works of the authors Jean Rhys (1890-1979) and Hella S. Haasse (1918-2011) uncover a temporal disunity at play on the threshold between colonialism and post/colonialism. Their works and lives seem to balance on the slash-sign I have inserted in 'post/colonialism' which serves both as a reminder of 
the continuation of global colonialist practices after the formal decolonisation of ex-colonies, and of decolonisation as a work-in-progress with no clear start and end dates. ${ }^{1}$ In their works, Rhys and Haasse challenge a unity of time by blending colonial pasts into the post/colonial presents of British and Dutch society. Rhys's and Haasse's Creole backgrounds further display a temporal disunity in the authors' acts of colonial re-patriation: their biographical movements from the colonial periphery, the British West and Dutch East Indies, to the metropolitan colonial centres, London and Amsterdam, respectively.

In this paper I will argue that the life trajectories of Haasse and Rhys express their own post/colonial 'belatedness. The way the authors have creatively re-worked and directed their individual Creole backgrounds into their novels, published in London and Amsterdam, can be seen as literary-creative nostalgias. I will not dismiss 'nostalgia' as a simply limiting and cliché sentiment, turned towards a static past, rather I argue along with, for instance, historian Jakob Dlamini (2010), who suggests that nostalgia can allow for complexity and highlight individual differences when dealing with politically troublesome collective pasts. In the case of Haasse and Rhys, their personal and literary-creative nostalgias invite me to map out their specific lives and works as challenging united master narratives of colonialism in post/colonial UK and Dutch societies.

Jean Rhys was born on Dominica in the British West Indies in 1890. She published four novels in the 1920s and '30s in the UK; they can be briefly (and superficially) described as depicting metropolitan women's lives in Paris and London. After a long period of literary-creative silence, she then published Wide Sargasso Sea in 1966. In this novel Rhys revisits Charlotte Brontës Jane Eyre (1847) and re-imagines the story of Mr Rochester's first wife, Bertha Mason, who is, as said in Jane Eyre, from the British Caribbean.

Hella S. Haasse was born in the Dutch East Indies (now Indonesia) in 1918; she published consistently in the Netherlands throughout the latter half of the 20th century. Both authors referred to themselves as 'Creoles', because they were born to colonial parents and educated in colonial settings. Rhys and, later, Haasse moved to Europe before the Second World War to study in London and in Amsterdam. Coincidentally - or perhaps not so coincidentally - they both started drama school. Instead of performers, however, Rhys and Haasse would become authors. Haasse's novels became better known and more widely read in the Dutch cultural field after the decolonisation of the Dutch East Indies; Rhys's work won acclaim in the British cultural field in the lead-up to the decolonisation of the British West Indies.

Rhys's and Haasse's colonial biographies are of relevance here, not simply because the authors indicated so in autobiographical writing, or because critics have foregrounded their colonial heritage - all of which is true - but primarily because their life trajectories as such challenge colonial temporal unity; they are 'belated' markers of the ambiguous project of colonialism. The postcolonial literary theorist Homi Bhabha explains what is 'belated' about the English book in colonial societies:

As a signifier of authority, the English book acquires its meaning after the traumatic scenario of colonial difference, cultural or racial, returns the eye of power to some prior, archaic image of identity. 
Paradoxically, however, such an image can neither be 'original' by virtue of the act of repetition that constructs it - nor 'identical' by virtue of the difference that defines it. Consequently the colonial presence is always ambivalent, split between its appearance as original and authoritative and its articulation as repetition and difference. (Bhabha, 2008b: 40, my emphasis)

The Western text in the colonial context thus becomes an almost schizophrenic signal that points to the ambivalence within the colonial system. In this paper, I argue that what Bhabha describes as an articulation of 'repetition and difference' in colonial contexts, further extends to texts published in-between colonialism and post/colonialism in Europe, outside the (former) colonies. Rhys's and Haasse's fictional texts have been particularly shaped by the real-life acts of colonial re-patriation. Rhys's and Haasse's geographical movement from colonisers' periphery to colonial centres as well as the fact that their oeuvres were published during the historical and political period of decolonisation in the UK and the Netherlands enabled them to act creatively and critically on threshold positions in-between colonial and post/colonial. Haasse and Rhys were actors in colonial 'belated' performances of re-patriation. Rhys had never been to England before moving there; Haasse had only spent short periods of her early childhood years in the Netherlands. The implicit suggestion in colonial society that re-patriation for children of colonial families meant a smooth return to a familiar motherland covers up the disjuncture at the heart of colonialism. Erica Johnson explains the problematic concept of repatriation and its dependence on the fiction of 'colonial return':

The concept of repatriation hinges on the notion of return [...] in the context of empire, the meaning of 'repatriation' is problematized by the logic through which colonialism poses a metropolitan 'motherland'/'fatherland' as an overarching point of reference. (Johnson, 2003: 20- 21)

Haasse's and Rhys's creative adaptations of their lives - creating aspects in their narratives that overlap with their real-life trajectories - then seem to be variations of what Gayatri Spivak, in reference to British-Indian author Salman Rushdie's Satanic Verses (1989), calls 'staging the author' (Spivak, 1990). ${ }^{2}$ Spivak regards Rushdie as 'writer-as-performer', which is particularly interesting with regards to Haasse and Rhys who happen to be performers-turned-writers. Rhys's and Haasse's writing motivations are different from someone like Rushdie who says about the Satanic Verses: 'I wanted to write about a thing that I find difficult to admit even to myself, which is the fact that I left home' (Rushdie quoted in Spivak, 1990: 45-46, my emphasis). Rushdie's 'guilt-tinted spectacles', as he describes it in his essay 'Imaginary Homelands' (Rushdie, 1991: 15) are directed at his migration from India: Rushdie wonders whether he is allowed to imagine his homeland after he has left India. With Rhys and Haasse, however, the idea of their childhoods, or their 'homes in the colonies', before they moved is the difficulty. The idea is questionable on account of the colonialist ambivalence of their enactment of repatriation, the dis-united 'colonial non-return' to the colonisers' centres London and Amsterdam. Looking back from these European capitals during the interbellum, the colonial childhoods - the 'homes' - of Rhys and Haasse have become haunted. The authors' nostalgias for their Creole homes, as creatively expressed in their work, are therefore 'unhomely' in Bhaba's 
understanding of the word: they are literary-creative projections of places that both unite and, simultaneously, disunite the public and the private; instances where past and present coincide, and the political and personal entwine (Bhaba, 1992). That Rhys's and Haasse's works about the colonies were published in the post/colonial 'motherlands' only articulates this unhomely act, injecting personal colonial histories into the global post/colonial present.

I will now discuss some extracts from the authors' works that indicate dis-united, imploded post/colonial time. I will focus on Rhys's earlier work, and Haasse's novel Sleuteloog (2002), keeping in mind that I cannot present a complete picture within the scope of this article. I will further mention some critical responses to these works in passing.

In Rhys's earlier work female (anti-)heroines roam the streets of Paris or London, often financially dependent on men. In contemporary reviews her novels are frequently described as 'sordid' or 'pitiful.' ${ }^{3}$ Though Rhys's protagonists seem passive, they are intelligent and creative, often describing situations with insightful understanding of social structures. The reader meets Marya, the protagonist of Rhys's first novel Quartet (1928; originally published as Postures, my edition: 2000a) when she embarks on a destructive triangular relationship in Paris. When she eventually makes love to her new lover, Heidler, she cannot help imagining the past. Marya practically becomes the past:

It was impossible, when one looked at that bed, not to think of the succession of petites femmes who had extended themselves upon it, clad in carefully thought out pink or mauve chemises, full of tact and savoir faire and savoir vivre and all the rest of it. (Rhys, 2000a: 87)

Later on Marya has a similar train of thought, imagining:

[...] all the women who had lain where she was lying. Laughing. Or crying if they were drunk enough. She felt giddy and curiously light, as if she were floating about bodiless in the scented dimness. (Rhys, 2000a: 93)

A procession of women from the past absorbs Marya into a timeless, ever-lasting, anonymous love affair - her present life becomes invaded by these historical women, hidden away in the anonymous hotel room. In Rhys's later work Voyage in the Dark (orig. 1934; my edition: 2000b) something similar happens: Anna, a young chorus girl, falls in love with an older man. The reader learns more about Anna's past than about Marya's in Quartet. Anna, like Rhys, is a Creole from Dominica; she has exchanged a warm island for cold, gray London; it is 'as if a curtain had fallen' (Rhys, 2000b: 7). Unexpectedly, in the narrative, Anna remembers the name of a slave on a document at her family's estate in Dominica. Here, now, it becomes clear that the history of colonialism is everything but one of white versus black. (This extract clearly stands out with its alternative use of punctuation):

Maillotte Boyd, aged 18, mulatto, house servant. The sins of the fathers Hester said are visited upon the children unto the third and fourth generation - don't talk such nonsense to the child Father said - a myth don't get tangled up in myths he said to me (Rhys, 2000b: 46) 
And Maillotte comes back once more, when Anna is making love to Walter; this time Anna's thoughts are clearly set apart in italics (by Rhys): 'Maillotte Boyd, aged 18. Maillotte Boyd, aged 18. ... But I like it like this. I don't want it any other way but this' (ibid.: 48). In this extract Maillotte Boyd's unhomely haunting frames an untold story within the told story of Anna lost in London. Anna's - perhaps intuitive - understanding of the ambivalence of colonialism becomes clear in her insertion of 'but' ('But I like it like this'). In this 'but' the character both represses, and rebels against, her family's involvement with colonial slave trade and exploitative abuse, as well as against her own dependence on Walter. I believe that this 'but' is comparable to the 'now of recognition' that Bhabha mentions in his Townsend Center Lecture (2008a). Bhabha argues with Walter Benjamin that 'no document of civilisation is not at the same time a document of barbarism. The framing of this barbaric document - the slave role at Anna's colonial home - within the present of Voyage in the Dark; the memory of her father calling interracial mixing 'a myth'; the inescapability of Maillotte's haunting when Anna herself is getting 'tangled up' in what is perceived as another sordid affair in an anonymous hotel room: all these indicate a re-charged colonial memory, what Bhabha would call a 'pressing now', a moment that injects the traumas of the past into the present. Bhabha argues that:

[...] we [should] take a double stance: if we must step into the stream of time, to feel the fast flow of progress and, at times, its cleansing [...] contemporality, we must also wade knee deep in the sewers of history, feeling [...] the tuck of the dark and the deep, and in the tension [...] there will emerge a current that sustains us. A current of creative communications that will not save us, but will at least give us some chance to survive. (Bhabha, 2008a)

How, then, is Anna of the 1910s related to Maillotte who, I believe, lived in the early 1800 s? I see Anna's plunge into the 'sewers of history' as a particularly challenging and positive way of re-imagining colonial pasts: it 'tucks' the contemporary reader towards the colonial 'dark and deep'. Anna's 'nomadic memory' of Maillotte Boyd is a way of, what Rosie Braidotti has called, 'reinventing a self as other [...] to actualize selfhood as a process of transformation and transversality' (Braidotti, 2011b: 33).

To highlight the silence of the contemporary critics regarding such 'pressing now'-s, I will discuss a much later text, by Hella S. Haasse. In Sleuteloog (2002), Haasse revisits her debut novel Oeroeg (1948) and discusses a friendship between a Dutch woman and a mixed-race Indonesian woman, both born in the Dutch East Indies. At the time of publication, Haasse was considered an established author with a literary career spanning more than 50 years; her publications had received plenty of coverage in the Netherlands' cultural field. In Sleuteloog Haasse presents an author with a Creole background named Eugene Mijers, effectively staging herself. This mise en abyme-structure in the novel is hard to miss; though I have not found a single Dutch literary critic who reflects upon this character. I find this remakable because the staging of Mijers can easily be seen as a dig at sentimental literary critics, nostalgics in the most traditional understanding of the word. The fictional Mijers creates a fictional family history, in order to claim his country of birth as a literary playground, re-visiting Orientalist stereotypes such as a sensual but heartless mixed-race mistress, or a quiet, submissive native nanny. The main character in Sleuteloog, Herma, looks 
For a while it looked as if there would be some sort of constructive role for those who thought they were allowed to stay by birthright. Eugene Mijers chose to be part of a disappointed, exiled group, and produced his own heritage with an Indonesian grandmother, and a stereotypical childhood in Java, strongly influenced by East-Indian customs and atmosphere. (Haasse, Sleuteloog, 2002: 107-108, my translation)

The staged author Mijers reproduces the colonialist idea that countries can be divided along clear racial lines: his imagined 'birthright' and imagined 'Indonesian grandmother' serve to provide him with a united, unambiguous identity. The real writer Haasse, though, reaches out of the unity of her novel. Haase directs the staged colonial author in what seems to be an invitation for readers to reflect upon a shared colonial past with all its complexities. Strangely, this case of Haasse-as-writer-as-performer was not picked upon in contemporary criticism. Though most Dutch critics anno 2002 responded positively to the novel, they cannot relate to what they see as an outdated theme, 'the East Indies'. I believe, in contrast, that Haasse has created a mosaic structure in Sleuteloog, continually switching between times and places - contemporary Indonesia, the Netherlands and the colonial past. The meta-critical reflection on the fictional author Mijers is just one example of such switches.

I discussed two diverse examples of framing colonial pasts in Rhys's and Haasse's post/colonial texts that activate complex, disunited pasts in the present. I also looked at the lives of Haasse and Rhys as markers of colonial ambivalence and disunity, and how their autobiographies have acted upon their texts about (former) colonies. I would like to end with a quote by Rosi Braidotti who builds on Deleuze's ideas about nomadic thought. Braidotti's work reminds us that theoretical and literary texts only makes sense when engaging with the real world. She describes postcolonial literature as follows:

[...] time is not frozen for the postcolonial subject and the memory of the past is not a stumbling block that hinders access to a changed present. Quite the contrary, the ethical impulse that sustains the postcolonial mode makes the original culture into a living experience, which functions as a motor for cultural self styling. [This] produces the core of the world's best literature. (Braidotti, 2011a: 60)

Haasse's and Rhys's work chimes with Braidotti's affirmative take on postcolonial literature. Indeed, these authors used their in-between lived experiences as motors for and in their post/colonial texts; they do not just display but also challenge complex colonial pasts in the present now of the Netherlands and the UK.

\section{Endnotes}

1 I use the slash-sign in 'post/colonialism' here in a similar way as Ania Loomba does in Colonialism/Postcolonialism (Loomba, 2005: p. 263). In this particular context, the sign also aptly illustrates the 'in-between' position of Haasse and Rhys.

2 In her article Spivak discusses Barthes' essay, 'Death of the Author'

(1968) in a postcolonial context. According to Spivak the Author as 'the authority of the meaning of the text' should indeed be questioned; the individual writer then becomes 'simply that someone who holdstogether in a 
single field all the traces by which the written text is constituted.' Spivak argues that the Author's presence is everywhere, embedding authority within historical contexts. She then explains that in the contemporary case of the Satanic Verses, the Ayatollah (who issued a fatwa to kill Rushdie) is the acting Author, and Rushdie the writer-as-performer.

$3 \quad$ For instance: The Times Literary Supplement calls 'The story of Marya [in Quartet] a peculiarly sordid one' (Beresford, 1928: 706); according to the Saturday Review Rhys's Voyage in the Dark has much 'sordidness and gloom' and is a 'pitiful little tale' (Anon., 1934: 468).

\section{Works Cited}

Anon.. 'Inside Out'. Saturday review of politics, literature, science and art, 158 (1934), p. 468.

Beresford, J. D. 'Postures.' The Times Literary Supplement (1928), p. 706.

Bhaba, Homi K.. 'The World and the Home', Social Text (1992), pp. 141-53.

- - '. 'On Global Memory: Thoughts on the Barbaric Transmission of Culture.' UC Berkeley. The Doreen B. Townsend Center for the Humanities. 14 April 2008a. Lecture.

- - -. 'Signs Taken for Wonders.' The Post-Colonial Studies Reader. Eds Bill Ashcroft, Gareth Griffins and Hellen Tiffin. $2^{\text {nd }}$ ed. London and New York: Routledge, 2008b, pp. 38-43.

Braidotti, Rosi. Nomadic Subjects: Embodiment and Sexual Difference in Contemporary Feminist Theory. 2nd ed. New York: Columbia University Press, 2011.

- - . Nomadic Theory: The Portable Rosi Braidotti. New York: Columbia University Press, 2011.

Dlamini, Jacob. Native Nostalgia. Auckland Park, South Africa: Jacana Media, 2009.

Gregg, Veronica Marie. Jean Rhys's Historical Imagination: Reading and Writing the Creole. Chapel Hill; London: University of North Carolina Press, 1995.

Hella S. Haasse. Sleuteloog. Amsterdam: Querido, 2002.

Johnson, Erica L. Home, Maison, Casa: The Politics of Location in Works by Jean Rhys, Marguerite Duras, and Erminia Dell'oro. London: Associated University Presses, 2003.

Loomba, Ania. Colonialism/Postcolonialism. 2nd ed. The New Critical Idiom. London: Routledge, 2005.

Jean Rhys. Quartet. London: Penguin, 2000a.

- - - Voyage in the Dark. London: Penguin, 2000b.

Rushdie, Salman. 'Imaginary Homelands.' Imaginary Homelands: Essays and Criticism 1981-1991. London: Granta, 1991, pp. 9-21.

Spivak, Gayatri C. 'Reading the Satanic Verses.' Third Text 4 (1990) : pp. 41-60.

\section{Biography}

Stefanie van Gemert gained both her MA in Dutch Language and Culture and her MRes in Literary Studies with Honours at the VU University in Amsterdam, NL. She is currently writing up her $\mathrm{PhD}$ thesis at the Comparative Literature department of University College London. Her research interests include the concept of 'nostalgia' in relation to colonial heritage and post/colonial art forms: her thesis particularly focuses on the reception of post/colonial literature that was published and re-worked in the Dutch and English cultural fields. 